\title{
Forest and environment: developments in global change ecology
}

\begin{abstract}
The knowledge and experiences in forest management requires the need for response to global change ecology and its interacting factors. This paper reviews the main perceived challenges that climate change poses to forests and global environment. At a global level and it is relevant to understand changing natural ecosystems whereby to all types of forests that include boreal, temperate, and tropical, to various management objectives (production, conservation, protection and multi- purpose) and to all types of management platform (public, private and community) are effected by environmental developments. This review paper addresses (1) Sustainable forestry concepts, (2) Environmental developments and (3) interacting factors of global change ecology and initiatives supported by international community with special interest in REDD+ and Carbon Initiatives. Generally, the functions of global institutions such as FAO enhances the development of models for forest dynamics, integration and analysis with reference to potential for solving climate change challenges in a global change ecology perspective.
\end{abstract}

Keywords: forestry management, environmental development, climate change ecology
Volume I Issue 3 - 2017

Toochi EC

Department of Forestry \& Wildlife Technology, Federal

University of Technology, Nigeria

\author{
Correspondence: Egbuche Christian Toochi, Department \\ of Forestry \& Wildlife Technology, School of Agriculture and \\ Agricultural Technology, Federal University of Technology \\ Owerri, Nigeria, Tel +234-8068093593, \\ Email ctoochi@yahoo.co.uk
}

Received: August 19, 2017 | Published: December 22, 2017

\section{Introduction}

Generally, the change in global ecology issue will affect almost all the forest conditions such as forest area, health and biodiversity and may increase growth rates in some areas while endangering the survival of species and forest communities in some other areas. Forest ecosystems are impacted by multiple uses under the influence of global drivers. The need for providing environmental services, forest ecosystem services and goods will be greatly influenced by changes in global ecology, posing some new challenges to forest and environmental sustainability. Societies are being forced to react to their perceptions of the real potential impacts of, the change in global ecology and considered as a result of unsustainable development. Water and desert lands accounts to only areas of the globe without forests, however, climate change on ecosystems as resulted to the development of both forests and environmental policies and legislation. The key development factor is anchored in sustainable forest management (SFM), and sustainable development which has been an influencing factor on the visions for forests, environmental development and associated principles been adopted by international community. SFM and sustainable development is aimed to reduce the risk of damage and possible losses from changing ecological conditions and also to undertake effective mitigation actions. The important factor is for the future opportunities to adapt and mitigate adverse climate change whereby development of ecosystem services that require monitoring for effective policy implementation. Forests and environmental development attracts wide range of management activities that will contribute to maintaining or increasing the adaptive capacity of global change ecology. Various management actions are being put in place and contribute to climate change mitigation through reducing emissions from forests, conserving forest carbon or enhancing forest carbon sinks. Forest carbon management offers potential for some immediate financial benefits. In addition, as a result of global change and climate challenges new international opportunities for financial and technical support for climate change adaptation and sustainable development are emerging.

\section{Forests and global change}

The world's forests are one of our greatest natural assets, providing innumerable ecological, social and economic services. They are also under more pressure than ever before, and face the consequences of rising human populations, the expansion of economic activities, and climate change. It is therefore vital that we adopt appropriate management practices to help ensure their ecological integrity and long-term sustainability in a changing world. Some literatures provided some strong evidence, understanding and predicting the consequences of these climatic changes on ecosystems is emerging as one of the grand challenges for global change scientists, and forecasting the impacts on forests is of particular importance. ${ }^{1,2}$ Forests, here broadly defined to include.

\section{Forest challenges, environment, sustainable development and climate change}

There are emerging threats to ecosystem functioning and biodiversity from climate change. Greenhouse gas emissions have significantly altered global climate, and will continue to do so in the future. Increases in the frequency, duration, and/or severity of drought and heat stress associated with climate change could fundamentally alter the composition, structure, and biogeography of forests in many regions. Forests, here broadly defined to include woodlands and savannas, cover $30 \%$ of the world's land surface. ${ }^{3}$ Climate change is widely accepted as one of the greatest global challenges today. ${ }^{4,5}$ Documented on detected impacts, vulnerability and projected impacts of climate change on forests found that impacts varied across the continents with some forest types being more vulnerable than others depicted in (Figure 1). Impacts included increased growth, increased frequency and intensity of fires, pests and diseases and 
a potential increase in the severity of extreme weather events (e.g. droughts, rainstorms and wind). Human activities, including forest conservation, protection and management practices, interact with climate change and often make it difficult to distinguish between the causes of changes observed and projected. Deforestation and fires in the Amazon region, for example, form a vicious circle with climate change, ${ }^{6,7}$ with the potential to degrade up to $55 \%$ of the Amazon rain forests. ${ }^{7,8}$

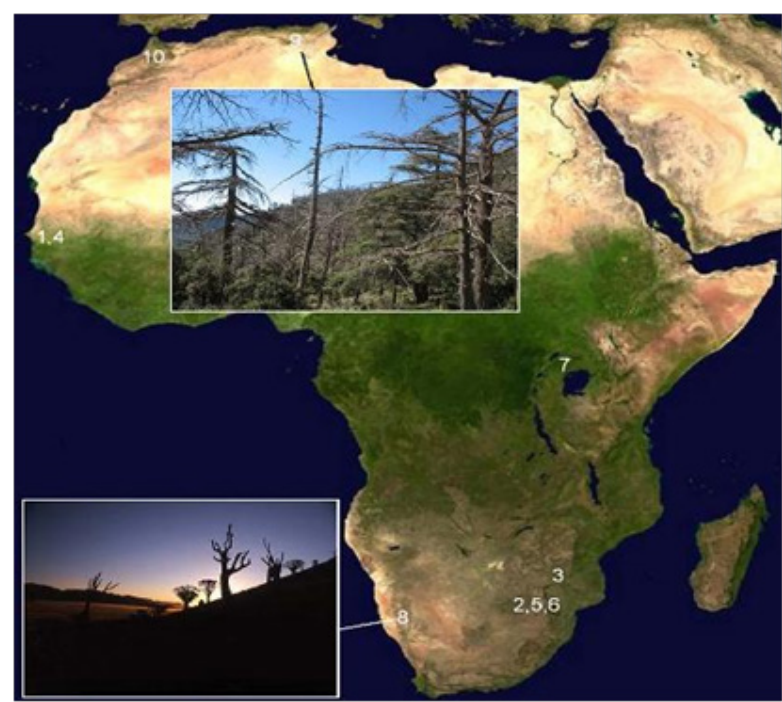

Figure I Satellite map of Africa, with documented drought-induced mortality areas indicated with numbers, tied to Table Al references. Upper photo: Cedrus atlantica die-off in Belezma National Park, Algeria; 2007, by Haroun Chenchouni. Lower photo: quiver tree (Aloe dichotoma) mortality in Tirasberg Mountains, Namibia; 2005, by Wendy Foden.Source. ${ }^{4}$

Documented evidence as in Lucier $\mathrm{A}^{4}$ further reported that it is very difficult to separate forest area change due to climate change from area changes due to other factors and has become a serious global challenge. FAO documented that at global level, planted forests and natural regeneration have increased the forest areas in some countries like the United States, Europe, China, and some countries in Latin America and the Caribbean e.g. Chile, Uruguay, Cuba and Costa Rica. ${ }^{9}$ On the contrary, FAO, $2009^{10}$ reported that some countries in Africa, Asia and the Pacific and the tropical countries of Latin America continue to be subject to deforestation (Figure 1), mainly due to conversion to small- and large-scale agriculture and livestock while deforestation in the boreal forests of Siberia is mainly due to forest fires. Climate change will increase the risk of frequent and more intense fires, especially where changing climate is accompanied by lower precipitation or longer dry periods as in the boreal, ${ }^{11}$ Mediterranean and sub-tropical forests ${ }^{5}$ and traditional land clearing practices as in the Amazon. ${ }^{6,7}$ Environmental facilities are land use based, together with land use changes, however, the effects of land use changes tends to be devastating - degraded and young forests are easily converted into agricultural land and pastures. ${ }^{12}$ However, such areas will ecologically recover over time. ${ }^{13}$ Many of the ecological processes that are needed for tree and other plant and animal species to live together are influenced by climatic conditions. The importance of climate for forest ecosystems and their composition and diversity is exemplified by the various global and regional vegetation classifications. Global change ecology issue brings about adverse environmental and human influences. Some forest plant species are able to adapt better to changing conditions than others, resulting in changes of composition of forest types, rather than geographic shifts of forest types. ${ }^{14}$

\section{Forest ecosystem services and underlying processes}

The Millennium Ecosystem Assessment ${ }^{15}$ documented that forest ecosystem services are defined as the benefits that people obtain from ecosystems. While many ecosystem services can be identified and are often grouped into four broad types of services, ${ }^{16}$ evidence of management and their relation with climate change and human wellbeing include productivity, carbon sequestration, soil/water protection and multiple socioeconomic benefits.

\section{Productivity}

Various literatures and documented evidences that include, ${ }^{17-24}$ revealed that the impact of climate change on productivity varies according to geographic area, species, stand composition, tree age, soils (mostly water holding capacity), effects of $\mathrm{CO} 2$ and nitrogen fertilization are based on interactions between geographic area, species, stand composition, tree age and soils factors. However, natural disturbances often decrease forest area, but through the damage on standing trees, also decrease productivity. ${ }^{7,25-27}$

\section{Carbon storage and sequestration}

There is an important interaction between carbon storage and sequestration by forests and changing temperatures and precipitation. On the one hand, the more carbon is stored in forests; less will be in the atmosphere. Increasing this stock will thus contribute to reducing the rate at which the global temperature is increasing. This relation has become extremely important in the climate change discussions and many tropical countries are preparing themselves to reduce emissions and increase forest carbon stock in order to capture part of the funding pledged for GHG emissions reductions. On the other hand, increasing temperatures longer dry seasons and increasing $\mathrm{CO}^{2}$ concentrations in the atmosphere in the long term, are expected to reduce the capacity of forests to store and sequester carbon, possibly converting forests from carbon sinks to carbon sources. ${ }^{7,20,23,24}$ Forests provides wood and non wood forest products which has been documented in its definitions and benefits as harvests of non wood forest products (NWFP) have three major functions: provision of part of the daily necessities of forest dependent people, off-farm income and a safety net in times of adverse conditions for agricultural production. Suggest that climate change will have impacts on the productivity of NWFPs and that NWFP users will largely be impacted through increased pressure on forest products from people that look for emergency supplies or alternative ways of income.

\section{Frontal challenges, opportunities and constraints posed by global change ecology to forest environmental management}

The global change ecology issues posed a serious threat to both forest environmental and of larger concern thereby poses new challenges, opportunities and constraints for forest environment management. These include changes in:

a. The natural environment, which is the basis for forest sustainable management.

b. The socioeconomic environment, particularly where local people depend heavily on the goods and services from forest ecosystems.

c. International and national policies and legislation, such as REDD+ agreements, land tenure agreements.

d. The markets, such as the carbon market, and 
e. Relations between different stakeholder groups, exemplified by the increased recognition of Indigenous Peoples.

These changes pose challenges for forest users. In some cases, they may be opportunities while in other cases they may constraints. This will depend on the user, type of use, geographic location and the current local socioeconomic and political situation. FAO have endorsed the concepts seven thematic elements for SFM.

\section{Summaries of changes in the natural environment that influences forest environment Strengthen adaptive capacity of forests}

Current forest composition and structure are however, the result of past changes in climate and shows that forests and their species have an inherent capacity to adapt to change. The main differences of current climate change with historic changes are the increased rate of these changes and the degraded and fragmented state of the remaining forests, which reduces the capacity of the species and ecosystems to adapt. ${ }^{28}$ The challenge is to help species and ecosystems to adapt to climate change while at the same time ensuring that ecosystem services are maintained. This will require the Identification of the changes to which the forest will need to adapt. Locally, changes may be disastrous, unless climate, ecosystem and species changes are accompanied by adjustments in the local social and economic systems. New challenges include the identification of those species groups and ecological processes that are essential for the most important ecosystem services. ${ }^{29,30}$ Documented and suggests that maintaining functional diversity and composition will preserve ecosystem services, while others found that different functional groups will react differently to environmental changes, ${ }^{31}$ indicating that climate change may favour some functional groups over others.

\section{Changes in socioeconomic environment}

\section{Risk of migration into forest areas}

Climate change will affect all people but in particular, rural people that depend on nature for their livelihoods, and poverty stricken communities in the urban-rural interface that are often subjected to the consequences of extreme weather events. Climate change is expected to change the aptitude of lands for specific crops, cause problems of droughts, fire and flooding and may drive many people from their lands. These people are likely to either go to cities to look for jobs, often adding to urban poverty, or to other rural areas to look for other lands where they may be able to continue their agricultural livelihoods or find employment in the agricultural sector. ${ }^{32-34}$

\section{Land tenure and other forest right issues}

Deforestation and forest degradation in tropical and some of boreal forests are serious problems that contribute to the emission of greenhouse gases as well as to the fragmentation of forests. Deforestation and degradation have a series of direct and underlying causes, ${ }^{35,36}$ but none of these can be resolved if land and forest tenure are not clear or are not enforced. ${ }^{37-40}$ State land is more frequently subject to conversion into agricultural land than privately owned land.

\section{Changes in policy environment}

\section{REDD+ expectations}

Probably one of the more notable short-term changes in the policy arena is the discussion of GHG emissions reduction through REDD + and management, conservation and restoration of forest carbon stocks. Large sums of money have been pledged against the demonstrable reduction of GHG emissions through REDD+, but so far, no international agreement has been reached on emissions reduction targets for developing countries. Further, in many pilot projects, measurable results have been interesting but financial benefits limited. REDD + expectations are manifold, depending on the interest group. Climate change will increase the challenge of designing and implementing new legislation that considers new international agreements, conflicts of interest in forest areas, as well as the need for coordination with other sectors. This may involve legislation on land and forest tenure, indigenous rights, the production of fuels and land use planning including restricting the access and use of certain areas or of some species, due to the risk of climate change impacts or the need of soil and water protection or maintenance of biological corridors.

\section{Forest and environment in the context of global change in the future initiatives}

The previous sections review the potential effects and significance of climate change on the forest sector. These impacts have varying consequences and are dealt with differently by forest managers. In this section, the possible operational options available to forest managers for addressing climate change mitigation and adaptation are assessed. In addition, the extent to which these options are being applied by forest managers is discussed, with the help of case studies. These examples, although not necessarily due to climate change, give good indications of what managers perceive to be good solutions to potential future changing climatic conditions.

\section{REDD+ framework initiatives}

Many of the actions oriented towards mitigation of climate change through REDD+ have a strong potential for synergies with actions oriented at strengthening the adaptive capacity of forests, in particular if such actions consider ecological safeguards, such as biodiversity conservation. Forest monitoring is very useful to detect changes due to climate change, natural disturbances or human activities. REDD+ is an international mechanism aimed at avoiding deforestation and forest degradation, promoting sustainable forest management and conservation or enhancement of the forest (carbon stock). The innovative part of REDD + is the broad international attention and the funding potentially available for the resulting strategies, the focus on carbon rather than on wood and NWFPs, and the recognition that the solution lies in an inter-sectoral approach rather than only within the forest sector. Because of the expectations REDD+ has raised, there are many actors involved, some of them seeing REDD+ as a means to strengthen their own agenda, developed over years or even decades. Foresters see REDD + as a means to bring forestry for timber management back on the foreground while conservationists focus on opportunities for protected areas. Many NGOs hope to be able to strengthen community forestry, while some indigenous people's organizations view the negotiations on REDD+ as a chance to finally receive formal recognition of their traditional rights. Many of the activities proposed under the REDD+ mechanism are not new but may be differently focused. The aim is to reduce emissions rather than produce specific products or conserve biodiversity. In addition, successful projects have clarified land, forest and carbon rights, recognizing legitimate claims of the different stakeholders, establishing acceptable cost and benefits sharing mechanisms and implementing activities to avoid negative social and environmental impacts, figure 2 shows functional and basic technical requirements pilot carbon initiatives. 
Functional and Basic technical requirements pilot carbon initiatives

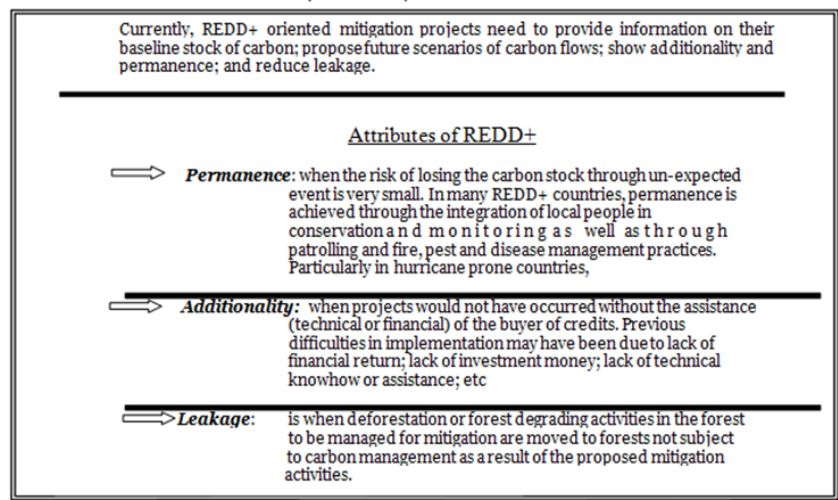

Figure 2 Functional and basic technical requirements pilot carbon initiatives. Modified from Allen et al. ${ }^{41}$

Very few of the projects have been designed to fit into national REDD+ strategies. However, lessons can be learned from the existing project experiences for implementation of the future strategies. Forest managers will most likely have to deal less with eliminating the underlying causes of deforestation and degradation, since many of those relate to policies, markets, culture and demographic factors such as population growth and migration. The major tasks for the forest manager within a national REDD + framework will be management and monitoring of the carbon stock. Managers will be motivated to do so if they perceive benefits from it, usually in the form of extra income and increased access to technical assistance and technology.

\section{The clean development mechanism and other carbon initiatives}

As documented by Allen AK et al ${ }^{41}$ that as early as 1995 the European Union set up the European Trading System (EU ETS), which puts a cap on the country emissions but allows EU countries to trade with other countries whose emissions remain well below the cap. Then in 1997, the Kyoto Protocol (KP) was adopted, although it did not enter into force until 2005. As of September 2011, 191 states have signed and ratified the protocol. Under the KP, 37 countries (Annex I countries) committed themselves to reducing their emissions to a level below that of 1990 and all member countries gave general commitments. They also agreed that countries that have not been able to meet their quota may compensate part of that by either setting up 'joint implementation' projects with other Annex 1 countries, or invest in Clean Development Mechanism (CDM) projects in developing countries (Non-Annex 1 countries). Of the latter, afforestation and reforestation are the only forms of forestry projects eligible. None of the tree or forest carbon offset projects however, are formally recognized within the framework of the ETS. Thus, options for forest carbon trade are limited to the voluntary markets and over the counter trade. In addition, funding is available to finance the costs of developing countries to prepare themselves for Reduced Emissions from Deforestation, Forest Degradation, forest conservation and sustainable forest management (REDD+). The delivery of funds to the countries has however, not reached expectations. Only around 1.5\% of the CDM projects, for example, are forestry projects, while at the same time, prices on the voluntary markets fluctuate with expectations of future demand but are very low.

\section{CDM projects}

Most carbon initiatives are either related to the CDM scheme or set up in a similar manner. These projects, with a few exceptions, are oriented toward sequestration of carbon. Trees are planted and a commitment is made to maintain the area under tree plantations for a minimum period of time, commonly 30years. Although within forestry circles this is thought to be a reasonable time period, it should be noted that if after thirty years the trees are cut and not replanted, in the long term no carbon has been sequestered, other than that used in long term products (permanence). In addition, the capacity of most tree species to sequester is relatively low. Official IPCC figures range from around $1 \mathrm{tC} / \mathrm{ha} / \mathrm{yr}$ to about $10 \mathrm{tC} / \mathrm{ha} / \mathrm{yr}$. Within the scheme, requirements for carbon accounting are very strict, raising the costs of entry and thus limiting the participation of small holders in the scheme. In voluntary y markets, carbon accounting standards may vary according to the expectations of the buyer. However, buyers are increasingly requesting the strict carbon accounting methods approved by $\mathrm{CDM}$, sometimes accompanied by standards that measure the social and economic impacts of these initiatives (Table 1).

Table I Forest and environment: developments in global change ecology future areas for further studies

\begin{tabular}{|c|c|c|}
\hline S. no & Key area & Broad and defined area for further studies \\
\hline I & Impact & $\begin{array}{l}\text { Impacts of climate change on the provision of forest and environmental products } \\
\text { and the subsequent socioeconomic effects, however, require more studies. }\end{array}$ \\
\hline 2 & $\begin{array}{l}\text { Ecosystem services and } \\
\text { goods }\end{array}$ & $\begin{array}{l}\text { To identify functional groups essential for the desired ecosystem services and goods in } \\
\text { particular areas and to understand how these can be conserved and protected. }\end{array}$ \\
\hline 3 & $\begin{array}{l}\text { Forest biodiversity and } \\
\text { structure in Africa }\end{array}$ & $\begin{array}{l}\text { The effect of climate change on forest biodiversity and structure in Africa and } \\
\text { the subsequent effect on attractiveness for tourists of many of the national parks need to be further studied. }\end{array}$ \\
\hline 4 & $\begin{array}{l}\text { Impact of climate } \\
\text { change on this } \\
\text { ecosystem service }\end{array}$ & $\begin{array}{l}\text { The impact of climate change on the ecosystem service, however, is still not very well understood, } \\
\text { since different species, different environmental and geological settings and different socioeconomic } \\
\text { conditions may affect the response of this service to climate change. }{ }^{41}\end{array}$ \\
\hline \multicolumn{3}{|c|}{ Issues addressed and projected for further direction } \\
\hline \multicolumn{3}{|c|}{ i. Terrestrial Ecosystems and landscapes and the biodiversity communities in them are undergoing change at local, regional and global scales } \\
\hline \multicolumn{3}{|c|}{ Drivers of change and emerging threats include climate change, deforestation, forest use, urbanization, thereby spreading global change ecology } \\
\hline iii. & $\begin{array}{l}\text { e are feedbacks and link } \\
\text { ent and ecosystem serv }\end{array}$ & $\begin{array}{l}\text { etween human interventions and environmental development. The future direction of forests, environmental deve- } \\
\text { s framework cannot explicitly address all knowledge and conceptual gaps }\end{array}$ \\
\hline
\end{tabular}




\section{Conclusion}

This review is presented with the content of forestry, environment and global change ecology embracing issues of climate change. It focuses on the various efforts projected by the global community such as REDD+ and carbon markets and other initiatives. However, areas of new direction for further studies are suggested as a major recommendation.

Other suggestions are presented below:

i. There is great interest among policy makers in the potential of carbon-based payments for ecosystem services (PES) to reduce carbon emissions from deforestation and protect forests in tropical countries.

ii. The further review how forest management is changing or could change in order to respond effectively to climate change challenges and opportunities.

iii. The potential impacts of climate on forests vary according to geographical region and local topography and land uses, but with only a few exceptions, temperature is expected to increase.

iv. Forest and environment have caused a redirection and focus for some global change ecology initiatives national, international and local level such as REDD+, Clean Development Mechanism (CDM) etc.

v. This paper presents a critical review of current trends in forestry concerns, development in environmental interactions in the face of global change ecology.

Generally, the main objective of this review was established and in line with $\mathrm{FAO}^{42}$ stating that the main challenges posed by global and climate change ecology for achieving the forest and environment management objectives rather pose some other direction for further studies are:

a) Improving the down-scaling of global change and climate change impact models and thereby incorporate more local information.

b) The potential strengthening effects of poor forest and environmental management on the impacts of global and climate change ecology.

c) Maintaining essential ecosystem services under changing conditions of global and climate change ecology.

d) Collaborative environmental management to reduce the negative impacts of the consequences of climate change and unsustainable environmental developments (e.g. fires and disease outbreaks).

e) Management of changing water resources.

f) Adaptation of management practices without introducing new problems.

g) Management of human migration due to the impacts of climate change elsewhere.

h) Adaptation of legislation to the demands of a changing world: in particular defining and protecting the rights over valuable products of ecosystem services, such as carbon. i) Adaptation of forest management to new market conditions, at the same time ensuring ecological integrity and social benefits.

j) Management of forests and trees as part of dynamic landscapes, in which forest managers interact with their neighbours in search for synergies and sustainable land management.

\section{Acknowledgements}

The author wish to thank and acknowledge FAO through the office of the Senior Forestry Officer (Forest and Climate Change) for the publication series produced by the Forest and Climate Change Programme of FAO, The views and presentation herein reflect and support to the reviews contained in Forest Management and Climate Change: a literature review of Forests and Climate Change Working Paper 10 but reviewed to pose some critical thinking in the future of global change ecology.

\section{Conflict of interest}

Author declares that there is no conflict of interest.

\section{References}

1. Boisvenue C, Running SW. Impacts of climate change on natural forest productivity evidence since the middle of the 20th century. Global Change Biology. 2006;12(5):862-882.

2. Bonan GB. Forests and climate change: forcings, feedbacks, and the climate benefits of forests. Science. 2008;320(5885):1444-1449.

3. FAO. Fire management voluntary guidelines. Principles and strategic actions. Fire Management Working Paper FM17E, Rome, Italy; 2006.

4. Lucier A, Ayres M, Karnosky D, et al. Forest responses and vulnerabilities to recent climate change. In: Seppala R, editor. IUFRO (International Union of Forestry Research Organizations) Secretariat, Wien, Austria; 2009.

5. Fischlin A, Ayres M, Karnosky D, et al. Future environmental impacts and vulnerabilities. In: Seppala R, editor. Adaptation of forests and people to climate change. IUFRO (International Union of Forestry Research Organizations) Secretariat, Wien, Austria; 2009.

6. Aragão LEOC, Malhi Y, Barbier N, et al. Interactions between rainfall, deforestation and fires during recent years in the Brazilian Amazonia. Philosophical Transactions of the Royal Society B: Biological Sciences. 2008;363(1498):1779-1785.

7. Nepstad DC, Stickler CM, Soares-Filho B, et al. Interactions among Amazon land use, forests and climate: prospects for a near-term forest tipping point. Philosophical Transactions of the Royal Society B, Biological Sciences. 2008;363(1498):1737-1746.

8. Nepstad P. The amazon's vicious cycles. Fire and drought in the greenhouse. Gland: WWF International; 2008.

9. FAO. Global forest resources assessment 2010: full report. FAO Forestry Paper 163, Rome, Italy; 2010.

10. FAO. Global review of forest pests and diseases. FAO Forestry Paper 156, Rome, Italy; 2009.

11. Burton PJ, Bergeron Y, Bogdansky BEC, et al. Sustainability of boreal forests and forestry in a changing environment. In: Mery G, editor. Forests and society-responding to global drivers of change. Wien, Austria: IUFRO World Series; 2010. p. 249-282.

12. Williamson M. Análisis multitemporal para la detección de cambios en el uso del suelo en tres municipios afectados por el huracán Juana. Wani. 2010;58:52-57. 
13. Vandermeer J, Cerda I, Boucher D, et al. Hurricane disturbance and tropical tree species diversity. Science. 2000;290(5492):788-791.

14. Breshears DD, Huxman TE, Adams HD, Zou CB, Davison JE. Vegetation synchronously leans upslope as climate warms. Proceedings of the National Academy of Sciences. 2008;105(33):11591-11592

15. Millenium Ecosystem Assessment (MEA). Ecosystem and human wellbeing: synthesis. Washington DC, USA: Island Press; 2005.

16. Dietz J, Hölscher D, Leuschner C, et al. Rainfall partitioning in relation to forest structure in differently managed montane forest stands in Central Sulawesi, Indonesia. Forest Ecology and Management. 2006;237(1-3):170-178.

17. Girardin MP, Raulier F, Bernier PY, et al. Response of tree growth to a changing climate in boreal central Canada: A comparison of empirical, process- based, and hybrid modelling approaches. Ecological Modelling. 2008;213(2):209-228.

18. LeBauer DS, Treseder KK. Nitrogen limitation of net primary productivity in terrestrial ecosystems is globally distributed. Ecology. 2008;89(2):371-379.

19. McMillan AMS, Winston GC, Coulden ML. Age-dependent response of boreal forest to temperature and rainfall variability. Global Change Biology. 2008;14(8):1904-1916.

20. Ollinger SV, Goodale CL, Hayhoe K, et al. Potential effects of climate change and rising $\mathrm{CO}_{2}$ on ecosystem processes in northeastern U.S forests. Mitigation and Adaptation Strategies for Global Change. 2008;13(5-6):467-485.

21. Phillips OL, Lewis SL, Baker TR, et al. The changing Amazon forest. Philosophical Transactions of the Royal Society B: Biological Sciences. 2008;363(1498):1819-1827.

22. Reich PB, Oleksyn J. Climate warming will reduce growth and survival of Scots pine except in the far north. Ecology Letters. 2008;11(6):588-597

23. Saigusa N, Yamamoto S, Hirata R, et al. Temporal and spatial variations in the seasonal patterns of $\mathrm{CO}_{2}$ flux in boreal, temperate, and tropical forests in East Asia. Agricultural and Forest Meteorology. 2008;148(5):700-713.

24. Clark DA, Piper SC, Keeling CD, et al. Tropical rain forest tree growth and atmospheric carbon dynamics linked to interannual temperature variation during 1984-2000. PNAS. 2003;100(10):5852-5857.

25. Chakraborty S, Luck J, Hollaway G, et al. Impacts of global change on diseases of agricultural crops and forest trees. CAB Reviews: Perspectives in Agriculture, Veterinary Science, Nutrition and Natural Resources. 2008;3(54):1-15.

26. Jepsen JU, Hagen SB, Ims RA, et al. Climate change and outbreaks of the geometrids Operophtera brumata and Epirrita autumnata in subarctic birch forest: evidence of a recent outbreak range expansion. Journal of Animal Ecology. 2008;77(2):257-264.
27. Kurz WA, Stinson G, Rampley GJ, et al. Risk of natural disturbances makes future contribution of Canada's forests to the global carbon cycle highly uncertain. Proceedings of the National Academy of Sciences. 2008;105(5):1551-1555

28. Noss RF. Beyond Kyoto: forest management in a time of rapid climate change. Conservation Biology. 2001;15(3):578-590.

29. Didham R, Ghazoul J, Stork NE, et al. Insects in fragmented forests: a functional approach. Trends in Ecology and Evolution 1996;11(6):255-260.

30. Tilman D, Knops J, Wedin D, et al. The influence of functional diversity and composition on ecosystem processes. Science. 1997;277:1300-1302.

31. Domingues TF, Martinelli LA, Ehleringer JR. Ecophysiological traits of plant functional groups in forest and pasture ecosystems from eastern Amazonia, Brazil. Plant Ecology. 2006;193(1):101-112.

32. Gemenne F. Climate-induced population displacements in a $4^{\circ} \mathrm{C}+$ world. Philosophical Transactions of the Royal Society A. 2011;369(1934):182-195.

33. Martin P. Climate change, agricultural development and migration. Washington DC: The German Marshall Fund of the United States; 2010.

34. Magrath J, Sukali E. The winds of change: climate change, poverty and the environment in Malawi. UK: Oxfam Research Reports, Oxfam International; 2009.

35. Kanninen M, Murdiyarso D, Seymour F, et al. Do trees grow on money? Forest Perspectives 4. Bogor, Indonesia: CIFOR; 2007.

36. Geist HJ, Lambin EF. What drives tropical deforestation? A metaanalysis of proximate and underlying causes of deforestation based on subnational case study evidence. LUCC Report Series 4, 2001. p. 1-136.

37. Corbera E, Estrada M, May P, et al. Rights to land, forests and carbon in REDD+: insights from Mexico, Brazil and Costa Rica. Forests. 2011;2(1):301-342.

38. Nawir AA, Kassa H, Sandewall M, et al. stimulating smallholder tree planting - lessons from Africa and Asia. Unasylva; 2007;228(58):53-58.

39. Walters BB, Sabogal C, Snook LK, et al. Constraints and opportunities for better silvicultural practices in tropical forestry: an interdisciplinary approach. Forest Ecology and Management. 2005;209(1-2):3-18.

40. Suyanto S, Applegate G, Tacconi L. Community-based fire management, land tenure and conflict: insights from Sumatra, Indonesia. FAO Regional Office for Asia and the Pacific, Bangkok, Thailand; 2002.

41. Allen CD, Macalady AK, Chenchouni H, et al. A global overview of drought and heat-induced tree mortality reveals emerging climate change risks for forests. Forest Ecology and Management. 2010;259(4):660-684.

42. FAO. Best practices for improving law compliance in the forestry sector. FAO Forestry Paper 145, Rome, Italy; 2005. 